\title{
Death Mask of Lucy
}

\author{
Dingming Wang \\ English Department of Literature and Law School of Sichuan Agricultural University, Ya'an, Sichuan Province, China \\ Dini Zhang \\ English Department of Literature and Law School of Sichuan Agricultural University, Ya'an, Sichuan Province, China
}

\begin{abstract}
As a great poet, William Wordsworth describes the death in many poems. Among them, Lucy poems are in a special group. They are not only poems concerning death but also love too. From a special perspective of lover, the poet describes five aspects concerning death: premonition of death, influence of death, meaning of death, attitude towards death, and significance of death. With these aspects, the poems reveal Wordsworth's contemplation of death. In addition, they justify that William Wordsworth practice his own poetics: the feeling therein developed gives importance to the action and situation, and emphasize the subjectivity of human being.
\end{abstract}

\section{Index Terms - wordsworth, death, Lucy poems}

William Wordsworth, the representative poet of the early Romanticism, was born in 1770. He greatly admired Nature, and emphasized imagination. His mother died when he was only eight. His father followed her six years later. The tragic experience in his children gives influence to his life. Poems concern about the theme of death. The Lucy poems are among those ones. The Lucy poems are a series of five poems written by Wordsworth during the year 1798 and 1801. The Lucy poems include "Strange fits of passion have I known", "She dwelt among the untrodden ways", "I travelled among unknown men", "Three years she grew in sun and shower", and "A slumber did my spirit seal". William Wordsworth wrote the poem during a short stay while he lived in Germany. In these poems, Wordsworth idealized a character of Lucy who died young. In Lucy poems, the death theme repeatedly appears and helps to understand the poetic of William Wordsworth.

In ancient Rome, the Romans kept the death masks of their forefathers as a way of remembering them (Stokstad, 1995, p.243). The death mask is made of wax. In Lucy poems, Wordsworth tries many ways to build a death mask of Lucy, as a special method of remembering a lady in his mind. Though some evidence may prove that Lucy in "Three years she grew" is Dorothy, Pipion also argues that Lucy poems are written under the inspiration of thoughts by Mary Hutchinson (Pipion, 1988, p.100-105). As Ferguson points out, though Lucy is the central figure in these poems, it is quite strange that "Lucy's voice is nonexistent in the poems" and, when she is about to speak, "she is silenced with death" (Ross, 1986, p.397). There is only the voice of I, the narrator of the poem. From feminism perspective, Ross criticizes that Wordsworth retains and intensifies masculine desire by killing Lucy, and, in relationship with Lucy, he deprives Lucy's needs and desires and keeps his needs and desires as the whole (Ross, 1986, p.399). Though the identity of Lucy and the purpose of these poems are in debating, it is clear that Lucy poems are filled with evidence of love and concern of death. Different from other poems about death of Wordsworth, like "We are seven", from a perspective of a lover, five aspects concerning death can be traced from the text: premonition of death, influence of death, meaning of death, attitude towards death, and significance of death. Each poem represents one aspect. From these poems, the worldview and the thought of death of Wordsworth are revealed little by little. Also, from them, it can find some evidence to justify that Wordsworth practices his poetics in his poetry, and gives emphasis to subjectivity, an important character of Romanticism.

The Lucy poems are in ballad measure, four-lined stanzas of alternating tetrameter and trimeter, rhyming abab. They are: "Strange fits of passion have I known", "She dwelt among the untrodden ways", "Three years she grew", "A slumber did my spirit seal", and "I traveled among unknown men". Except the last one, all poems were written in 1799, when Wordsworth and his sister, Dorothy, were in Germany. The winter in Goslar was severe, and Wordsworth had nothing to do except writing poems. In this period, Wordsworth wrote some early important poems, such as Lucy lyrics, and narrative description of boyhood experiences (skating, the "stolen" boat, episode, "Nutting") (Pipion, 1984, p.34). Under such kind of circumstance, Wordsworth gave his poems the thought about life; Lucy poems are his thoughts about death at that time. Though his mother died early, his first sight of a drawn man at Esthwaite was somewhat near. He was not yet nine years old at that time. He thought he was lack of fear because he looked at such sights in the fairy world of romance (Pipion, 1988, p.3). But the Wordsworth in Goslar is quite different from the young boy. He was growing into maturity, and had much experience about life. As Williams points out that Goslar is "the crucible of Wordsworth modernity" (Pipion, 1988, p.103), Wordsworth was at a turning point in his life.

In Lucy poems, there are some aspects of death. When they are put together, a death mask of Lucy, an imaginary lady in Wordsworth's mind, appears in the mind of the reader, like the death masks of Roman ancestors. It is the memory of Lucy. On the other hand, it is clear that Lucy poems are love poems because it can find evidence in the 
poems that the narrator loves Lucy deeply. In the first poem, "Strange fits of passion have I known", the narrator says plainly Lucy is "she I loved".

At the beginning of the poem, the narrator boldly says that he will tell the other lovers the "strange fits of passion" once befell to him. At that time, Lucy was young as "a rose in June". In order to see her, the narrator rode to her cottage under "an evening moon". Having passed the dear paths, "reached the orchard-plot", "climbed the hill", at last, he arrived at the cottage with his horse. On his way to the cottage, the moon accompanied him: the sinking moon, the descending moon, and the bright moon. The image of moon gives an impression of special meaning. In ancient Greek mythology, the goddess of Moon is Diana. She is worshiped as the goddess of hunting and childbirth (Frazer, 1963, p.4). In this case, the moon is related as Diana. With the company of goddess, the narrator "never stopped" on his way to find his lover. Actually, "the descending moon" was coming "near, and nearer still". With the blessing of Diana, the narrator believed that he would meet his lover, and make a union. But when he came "down behind the cottage roof", and fulfilled his goal, meeting his lover, the moon "dropped" and disappeared. This may be explained as a good scene for two lovers meet each other. But from the narrator, it is different. With such a change, the narrator suddenly had a different idea in the mind, the premonition that Lucy would die one day. With the company of Diana, the narrator was promised to find his lover and give birth to a child. After his meeting of his lover, she disappeared. Her bless fell on the narrator instead of his lover. The lover was lack of one important thing, the eternal life. Diana fulfilled her promise and left him alone. It means that death is something Lucy could not avoid. From ancient time to present, people tried every many ways to gain an eternal life. In Renaissance, people believe that poems can make people eternal. This idea reflects in many works (cf. Sonnet 75 of Spenser, Sonnet 18 and 55 of Shakespeare). When he was 11 or 12 years old, Wordsworth was persuaded to memorize long passages of Milton, Shakespeare, and Spenser by his father (Pipion, 1988, p.3). Though little evidence is found to prove what poems Wordsworth had read, it is no doubt that Wordsworth is familiar with those poems and believes the power of poetry can eternize a person. From this poem, the thought about the coming death proves that Wordsworth is conscious that the human body is mortal. For an individual, he is destined to die one day. What Lucy will leave him after her death is the memory of the meeting time and the premonition of her death in their gathering. Wordsworth calls the premonition of lover's death the "fond and wayward thoughts", because, when one is deep in love, he or she seldom thinks that their lovers will die one day. Even he is aware of the future, the inevitable death, he just tries his effort to make his lover immortal, just like the poets in Renaissance. But as an "outsider" (Williams, 1993, p.104), Wordsworth distinguishes the death of man in several aspects. With poems, a person is immortal to all readers. But this immortality lies in the thought of the readers, in another word, in spirit, not in body. The human body will perish one day. With two words of "fond and wayward", Wordsworth set emphasis to give strangeness of the premonition of death in a lover's eyes. The death is inevitable, but one tries to forget it. The sharp contrast intensifies the strength of poem. With such emphasis, a gloomy mood raises in the reader. Like Pipion points out, Wordsworth is interested "in the working of the mind at a point of heightened emotion" (Pipion, 1984, p.104). With this intensity, it gives the action and situation, and not the action and situation to the feeling (Wordsworth, 1974, p.73). In such circumstance, it can induce another popular theme of love in Renaissance - carpe diem. While one is still alive, one should make use of time and pursue love. If he fails to do so, he gets nothing, even without the memory of his lover. With the premonition of lover's death, Wordsworth reveals one character of death: inevitability. As Heidegger says, "Being towards death" (Wordsworth, 1974, p.277), no one can escape this fate. Wordsworth creates a different way in the poem In the second poem, "She dwelt among the untrodden ways", the poet talks about the influence of death.

From what the narrator says, the influence of death is connected with the position of person. In the first stanza, the narrator indicates the trivial social position of Lucy. Dove is the name of several rives in England (Abrams, 1993, p.153). It means where Lucy once lived is a common place in England. It could be the Lake District, or other places. "The untrodden way" shows it is a remote countryside and few people go there. Her social circle is small. This limited surrounding gives the impression of Lucy: she is just like a hermit. In this case, she is so trivial that could hardly be noticed by the society. But this does not mean she is low in social class. Though to the whole society she is trivial, but to those who know her, she is very important. In the second stanza, the poet uses two images to make a sharp contrast of her position to the society and her lover. To the society, she is "a violet by a mossy stone", a most common thing in England. Here, Lucy is no longer a rose in the first poem, but a violet, a very common flower found everywhere. She is modesty to the society, and also obscure and unnoticed, because she is "half hidden from the eye". The image of violet enhances her humble position in the society. But to her lover, she is "fair as a star, when only one / Is shining in the sky. After the sunset, the first star shining in the sky is Venus. In Greek mythology, Venus is the goddess of beauty and love (Car-Gomm, 1995, p.220). To her lover, she is beautiful and is the planet of love itself. She represents all his love. With this sharp contrast, the poem reveals two sides of a human being, both trivial and important. To society, she is trivial; to those who love him, he is important. So Lucy's death has little influence to the society because "few could know / When Lucy ceased to be". But to her lover, it is quite different. Lucy is in her grave and is different to him. In the lover's eyes, Lucy could not speak to him and takes away all his love. It is not what John Donne called "one short sleep" (Abrams, 1986, p.1099), but the "decay" of "a mortal thing" (Spenser, 1993, p.617). For the narrator, it is in deep grief of his lover's death. This sharp contrast may raise a thought in the reader's mind as an allegory. Everyone in this world is like Lucy, both trivial and important. Though death of some great people will give shock to the society for a while, but the society returns its route because it is the society of all human beings, not of an individual. Man is 
relatively humble in the society, though he is once a great man in this world. With the consciousness of humility, he should be conscious of his importance to the people who love him. He is the source of their love and joy. So with the contrast of humility and importance, the influence of death is put in the mind. With the revelation of the influence of death, Wordsworth shows man's humility and the meaning of life.

In the third poem, "Three years she grew", the poet put a discussion on the meaning of death. In this poem, Lucy is described as a child died young. When Lucy was three years old, Nature made his promise to make her "a Lady of my own". So in the realm of nature, she is "sportive as the fawn" and springs "across the lawn or up the mountain", and she has the characters of "the breathing balm", and "the silence and the calm / Of mute insensate things". Because she is the "Lady" of Nature, she shares the honour of nature, that "the floating clouds" give her their state; "the willow bend" to her, "The stars of midnight" are "dear to her". She is part of Nature. As many Romantic poets worship Nature, the Nature is the best thing they can find in their poems. As a part of Nature, Lucy represents the best thing in this world. But from a feminist view, Ross discusses social meaning of word lady and looks Nature as "the representative of Man" (Ross, 1986, p.399-401). This explanation shows the voiceless Lucy's position in the narration of man, but, in the poem, the transformation of Lucy's role gives an objection to this argument. From the very beginning, Lucy was under the bless of Nature as the Lady of Nature. Later, the narrator changes his words as he calls her, "my Lucy". There is an assumption that the narrator is a man. If the narrator is Lucy and she says her lover's race is end, it cannot say Nature is the representative of Woman. In this case, "my Lucy" may only mean her role has transformed from a natural one to a social one. In Nature, there is no death and Lucy is alive. This idea may trace back to the ancient time. In Greek myth, for her love to Hippolytus, Diana restored his life. In order to escape from the angry god, Jupiter, she took him to the dells of Nemi and prolonged his life (Frazer, 1963, p.6). So in Nature, man can find an eternal life. Lucy and Nature live in "happy dell" implies that, in Nature, she can live as long as possible. So in nature, there is no death. But when she is in society, she died. She left the narrator "this heath, this calm, and quiet scene". He cannot have her company in those places as the old time. He only has memory of her. With the sharp contrast, the poem reveals that death only has social meaning. As a natural being, a part of the Nature, man shares the character and honour of Nature, and runs in the great circle of nature. Death means he changes from this form to that form. It makes no difference what form he is in the great circle of nature. He is Nature itself. But as a social being, man is an individual in the society. He has relations with others. His change of form, death, gives impact to others, just like the death of Lucy only leaves memory to her lover. In some cases deaths is like the absence of something. It only disappears in some place but appears in another place. It breaks the social relationship. So the death of a person only has meaning in human society. It means the breaking of social relationship. It is the death in the society that Wordsworth reveals death only exists in the society. It has social meaning.

The fourth poem, "A slumber did my spirit seal", is the shortest one but receives much attention from critics, such as from F. W. Bateson and Cleanth Brooks to Paul de Man and J. Hills Miller (Curran, 1993, p.234). Pipion argues it is "philosophical and detached rather than personal; it excites reflection rather than emotion" (Curran, 1993, p.105). Williams (1993) thinks that Goslar is "a slumber" in Wordsworth's life when he discusses his modernity (p. 103). With its simplicity, the poem discusses what kind of attitude man should take to death. When my spirit was sealed with a slumber, "I had no human fear". Slumber is one kind of sleep. In a slumber state, the narrator has no consciousness. Any knowledge of human being does not exist in his mind. He is in a state of innocence. In his Holy Sonnet 10, Donne compares death as a short sleep as he proudly claims the eternal life towards death. But for most human being, the fears in life are fear of death. It concerns about the consciousness of death. When a man does not have the idea of what is death, he is not afraid of death. So does she, the girl in this poem. Since she grows in nature and has no knowledge of human being in her mind, she too has no concept of death. In the narrator's eyes, she naturally "could not feel / The touch of earthly years" because her innocent state of human knowledge. This case is linked to what Rousseau called conception of noble savage. She lived "with rocks, and stones, and trees" "in earth's diurnal course". She has no idea of death at all. Having described the situations without the fear of death, Wordsworth suggests possible attitudes towards death. Though death is inevitable, but one can avoid the fear of death. First, death is a slumber, a state that one can ephemerally forget the notion of death. Since one forgets the notion of death, he will deprive the fear of death in that forgetfulness. Second, one lives in nature and is instilled with natural knowledge, without the human knowledge of society, like the girl in the poem. So he has no fear of death. Since man is social animal and lives in a society, he is hardly to survive in the society without the knowledge of human being. The most possible way to deprive the fear of death is to forget the notion of death in human mind. With this description, Wordsworth suggests the potential attitude towards death, forgetting death. There are some people who can escape the fear of death with their wits, like Socrates, but not all human beings can follow his way. For Wordsworth, in order to escape the fear of death, the best way for most people is to forget the notion of death, such as in a state of slumber. Though it is a passive way, it is in fact an effective way for all human being to deprive the fear of death.

For the last poem, "I travelled among the unknown men", it is supposed that Lucy is Mary Hutchinson. In April 1801, Wordsworth sent a copy of this poem to Mary Hutchinson, and ended "God for ever bless thee, my dear Mary - Adieu" (Pipion, 1988, p.43). As a love poem, it also reveals the significance of death. In the poem, the narrator tells how he develops his patriotism. He finds his love for England when he travels in the foreign country, "among unknown men". It is not easy for him to recognize it when he is in England. Then, he swears he will not leave his country "a second 
time" because he loves her "more and more". Though the poem is not written in German, it reflects some thought of Wordsworth and Dorothy in Germany. The severe weather made them homesick and they decided to live in Lake District. The description is the true state of their minds at that time. The narrator feels the joy of his desire among the mountains in England. But from where comes his patriotism? There are many reasons. But in this poem, it is the death of Lucy which raises his patriotism. England is the place where Lucy lived: "Thy mornings showed, thy nights concealed the bower where Lucy played". And also, it is the place where Lucy died: "And thine too is the last green field that Lucy's eyes surveyed". Death of Lucy leaves the narrator only memory and deep grief. In reality, he only finds the places where Lucy once lived. They may recall his memory of her. England becomes important to the narrator because of the death of Lucy. With the feeling of the narrator, all things described are important. It is clear this is what Wordsworth says, "the feeling therein developed gives importance to the action and situation" (Wordsworth, 1996, p.7). It is the feeling of the narrator that gives importance to England and develops his patriotism. So it is the death of Lucy gives significance to England, and the narrator's memory of Lucy makes England important to him and develops his patriotism.

With the above discussions, it shows Wordsworth reveals five aspects concerning death from a perspective of a lover: premonition of death, influence of death, meaning of death, attitude towards death, and significance of death. It reflects Wordsworth's contemplation of death. Together with other poems concerning death, Lucy poems give Wordsworth's worldview. The feeling therein developed occupies the most important position in all the poems. It justifies Wordsworth's poetics. On the other hand, it also shows importance of the subjectivity of the individual. Death of individual only has social meaning. With this understanding, one can understand Wordsworth better.

\section{REFERENCES}

[1] Abrams, M. H. ed. (1986). The Norton Anthology of English Literature. (5th edn). Vol. 1. New York: Norton.

[2] Abrams, M. H. ed. (1993). The Norton Anthology of English Literature. (6th edn). Vol. 2. New York: Norton.

[3] Car-Gomm, Sarah. (1995). The Dictionary of Symbols in Western Art. New York: Facts on File.

[4] Curran, Stuart ed. (1993). The Cambridge Companion to British Romanticism. Cambridge: Cambridge UP.

[5] Frazer, James George. (1963). The Golden Bough: A Study in Magic and Religion. Abridged ed. London: Macmillan Co. Ltd.

[6] Heidegger, Martin. (1999). Being and Time. Trans. John Macquarrie and Edward Robinson. Beijing: China Social Science Publishing House and Chengcheng Books Ltd.

[7] Pipion, F. B. (1988). A Wordsworth Chronology. London: Macmillan Press.

[8] Pipion, F. B. (1984). A Wordsworth Companion: Survey and Assessment. London: Macmillan Press.

[9] Ross, Marlon. (1986). “Naturalizing Gender: Woman's Place in Wordsworth's Ideological Landscape.” ELH, 53, 2, p.391-410.

[10] Spenser, Edmund. (1993). Edmund Spenser's Poetry: Authoritative Texts Criticism. Ed. Hugh MaClean and Anne Lake Prescott. (3rd edn). New York and London: Norton and Company.

[11] Stokstad, Marilyn. (1995). Art History. Vol. I. New York: Prentice Hall, Inc., and Harry N. Abrams, Inc.

[12] Williams, John. (1993). William Wordsworth: A Literary Life. N Y: St. Martin's Press.

[13] Wordsworth, William. (1974). Wordsworth's Criticism. Ed. W. J. B. Owen. London and Boston: Routledge \& Kegan Paul.

[14] Wordsworth, William. (1996). Selected Poems. New York: Penguin Books Ltd.

Dingming Wang was born in Qionglai, Sichuan Province, China in 1975. He received his M. A. degree in literature from Southwest University, China in 2007.

He is currently a lecturer in English Department of Literature and Law School, Sichuan Agricultural University, China. His research interests include English literature and American literature.

Dini Zhang was born in Huaiyang, Henan Province, China in 1982. She received her M. A. degree in literature from Hunan University, China in 2008.

She is currently a lecturer in English Department of Literature and Law School, Sichuan Agricultural University, China. Her research interests include English literature and American literature. 